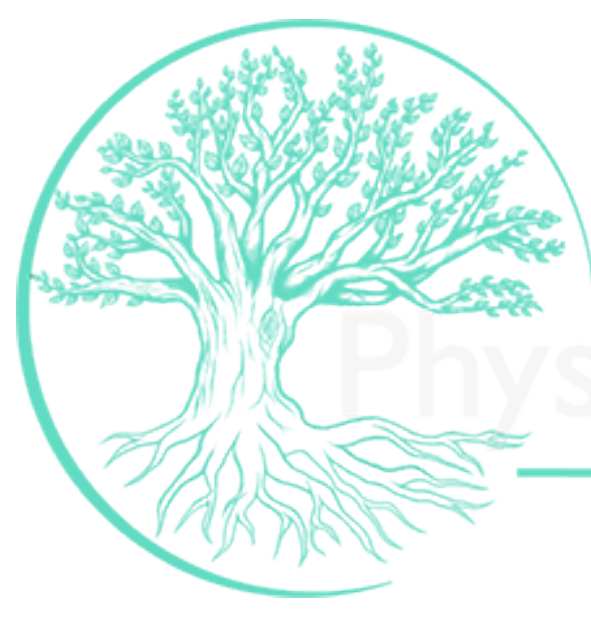

\title{
The interplay of hydraulic failure and cell vitality explains tree capacity to recover from drought
}

\begin{tabular}{|c|c|}
\hline Journal: & Physiologia Plantarum \\
\hline Manuscript ID & PPL-2020-00725.R1 \\
\hline Manuscript Type: & Regular manuscript - Ecophysiology, stress and adaptation \\
\hline $\begin{array}{r}\text { Date Submitted by the } \\
\text { Author: }\end{array}$ & $\mathrm{n} / \mathrm{a}$ \\
\hline Complete List of Authors: & $\begin{array}{l}\text { Mantova, Marylou; INRAE- University Clermont Auvergne } \\
\text { Menezes Silva, Paulo; Instituto Federal de Educação Ciência e Tecnologia } \\
\text { Goiano - Campus Rio Verde, Department of biology } \\
\text { Badel, Eric; INRAE - University Clermont Auvergne } \\
\text { Cochard, Hervé; INRA Centre Clermont-Ferrand-Theix-Lyon } \\
\text { Torres-Ruiz, José M.; INRAE - University Clermont Auvergne, PIAF }\end{array}$ \\
\hline Key Words: & cavitation, drought, tree mortality, cell death, Plant Hydraulics \\
\hline
\end{tabular}


1 The interplay of hydraulic failure and cell vitality explains tree capacity to 2 recover from drought

3

4 Marylou Mantova ${ }^{1}$, Paulo E. Menezes-Silva ${ }^{2}$, Eric Badel ${ }^{1}$, Hervé Cochard ${ }^{1}$, José M. Torres5 Ruiz $^{1, *}$

6

7 'Université Clermont Auvergne, INRAE, PIAF, 63000 Clermont-Ferrand, France

8 2Laboratório de Fisiologia Vegetal, Instituto Federal de Educação, Ciência e Tecnologia Goiano, IF 9 Goiano, 75901970 Rio Verde, Brasil

10

11 Correspondence

$12 *$ Corresponding author,

13 e-mail : torresruizjm@gmail.com

14 


\section{Abstract}

16 Global climatic models predict an increment in the frequency and intensity of drought events, which 17 have important consequences on forest dieback. However, the mechanisms leading to tree mortality 18 under drought conditions and the physiological thresholds for recovery are not totally understood yet. 19 This study aimed to identify what are the key physiological traits that determine the tree capacity to 20 recover from drought. Individuals of a conifer (Pseudotsuga menziesii M.) and an angiosperm (Prunus 21 lusitanica L.) species were exposed to drought and their ability to recover after rehydration monitored. 22 Results showed that the actual thresholds used for recovery from drought based on percentage loss of 23 conductance (PLC) (i.e. 50\% for conifers, $88 \%$ for angiosperms) do not provide accurate insights about 24 the tree capacity for surviving extreme drought events. On the contrary, differences in stem relative 25 water content $\left(\mathrm{RWC}_{\mathrm{Stem}}\right)$ and the level of electrolytes leakage (EL) were directly related to the capacity 26 of the trees to recover from drought. This was the case for the conifer species, P. menziesii, for which 27 higher $\mathrm{RWC}_{\text {Stem }}$ and lower EL values were related to the recovery capacity. Even if results showed a 28 similar trend for the angiosperm P. lusitanica as for the conifers, differences between the two traits were 29 much more subtle and did not allow an accurate differentiation between trees able to recover and those 30 that were not. $\mathrm{RWC}_{\text {Stem }}$ and EL could work as indicators of tree capacity to recover from drought for 31 conifers but more studies are required to confirm this observation for angiosperms. 


\section{Introduction}

Forests represent ca. $30 \%$ of the global continental surface (FAO 2006) and provide society with several ecosystem services such as timber production, watershed protection (Allen et al. 2010), hosting biodiversity (Trumbore et al. 2015), and carbon storage and its associated atmospheric feedbacks (Reichstein et al. 2013). Due to the ongoing climate changes and global warming (IPCC 2014), not only the frequency of heatwaves and drought events have increased in many areas worldwide but also their duration and intensity (Allen et al. 2010). A recent data synthesis has suggested that the majority of plant species converge to narrow hydraulic safety margins and thus are very susceptible to changes in rainfall patterns (Choat et al. 2018). Therefore, these higher frequencies and increased severity have exacerbated the occurrence of drought-induced tree mortality events (Keenan et al. 2013, Duan et al. 2014) and, consequently, forests dieback (Hosking and Hutcheson 1988, Lwanga 2003, Landmann and Dreyer 2006).

Although the reduction in water availability can affect virtually all processes associated with plant growth and development, drought-induced tree mortality events are commonly associated with two main processes: carbon starvation and xylem hydraulic failure (McDowell et al. 2008). Under prolonged mild drought conditions, trees partially close their stomata to reduce evapotranspiration and hence the risk of xylem hydraulic failure. However, this stomatal closure constrains $\mathrm{CO}_{2}$ diffusion in leaves and can lead to an important depletion of the carbohydrate pools resulting in carbon starvation (Hogg and Hurdle 1997, Buckley 2005, McDowell et al. 2008, Berry et al. 2010, Creek et al. 2020). Even if carbon starvation and xylem hydraulic failure cannot be considered as mutually exclusive processes, recent studies have shown that xylem hydraulic failure is the main cause of tree mortality under severe drought (Urli et al. 2013, Salmon et al. 2015, Adams et al. 2017). Xylem hydraulic failure occurs when the tension in the continuous columns of water that connect the roots with the leaves through the xylem increases and, consequently, exacerbates the risk of cavitation (breakage of the water column) (Tyree and Zimmermann 2002). This process is widely amplified as soil dries or when the evaporative demand increases. Thus, under extreme drought conditions, as the percentage of cavitated conduits increases, the hydraulic conductance of the xylem decreases until the flow of water stops and provokes the desiccation of the plant tissues, cells death and, finally, the death of the tree (McDowell et al. 2008). This makes xylem vulnerability to cavitation one of the main physiological traits when evaluating drought-induced mortality.

Even if the vulnerability to cavitation has been widely evaluated for an important amount of species during the last decades (Delzon et al. 2010, Choat et al. 2012), the relationship between xylem hydraulic failure and tree mortality has not been properly evaluated yet. It is known that $P_{50}$ and $P_{88}$ (i.e. the xylem tension inducing 50 and $88 \%$ of loss of hydraulic conductance, respectively) are associated with the capacity of the trees to recover from drought (Brodribb et al. 2010, Delzon and Cochard 2014, 
Sperry and Love 2015, Bolte et al. 2016), but the physiological causes of tree death under extreme drought events remain unclear. Therefore, due to a lack of physiological thresholds to properly define tree mortality both during or after a drought episode, $P_{50}$ and $P_{88}$ values, for conifers and angiosperms respectively (Brodribb and Cochard 2009; Urli et al. 2013), are currently used as proxies for mortality when e.g. modelling the trees' response to drought (Martin-StPaul et al. 2017). However, a recent study by Hammond et al. (2019) reported that the appropriateness of $P_{50}$ as an indicator of mortality for conifers should be reconsidered as they defined a lethal threshold at $80 \%$ of loss of xylem hydraulic conductivity in loblolly pines (Pinus taeda L.). Also, it has recently been reported that branch diameter variations were revealing a point of no recovery in lavender species as plants were not able to recover from drought once their elastic water storage localized in the bark were depleted (Lamacque et al. 2020). These results have raised new questions about the role of xylem hydraulic failure in triggering tree mortality or the minimum hydraulic functioning required for allowing trees to survive and recover from drought.

The ability of the trees to recover after a drought event seems to be tightly related to their ability to grow new xylem (Brodribb et al. 2010) and this ability must be intrinsically linked to their capacity to maintain key living tissues alive in perennial organs, as the stem, that allow them to regrowth and resprout in favourable conditions. Considering the tenet that xylem hydraulic failure should provoke the complete desiccation of the cells and their consequent death leading to whole plant mortality (McDowell et al. 2008), a focus on plant water status and its consequences on cell vitality seems necessary to understand drought-induced mortality (Guadagno et al. 2017, Martinez-Vilalta et al. 2019). This, therefore, highlights the relevance of relative water content (RWC), a direct measure of the plant water status at cell level, as a potential candidate for assessing drought-induced tree mortality (MartinezVilalta et al. 2019, Trueba et al. 2019). In addition, and considering that many studies have evinced how low RWC values are linked to membrane dysfunction in plant cells (Wang et al. 2008, Chaturvedi et al. 2014), combining both traits, RWC and membrane dysfunction, would help define physiological thresholds for tree mortality.

The main objective of this study was to identify other physiological traits than the percentage loss of hydraulic conductance (PLC) that could work as an indicator of the tree capacity to recover from drought. For this, a set of plants of Prunus lusitanica L. and Pseudotsuga menziesii M., i.e. an angiosperm and a conifer species respectively, were exposed to severe drought conditions and allowed to dehydrate until the induction of important losses in hydraulic functioning. At this point, trees were re-watered to check for the capacity to recover from drought. During the dehydration and the recovery phases, we monitored embolism formation and changes in RWC at the stem and the leaf level. We also monitored changes in stem diameter to check whether trees were able to recover from drought after being re-watered, and assessed the vitality of the stem living tissues. Results also provided us with novel 
103 information about the causative relationship between PLC and tree mortality and the level of PLC that 104 prevent any recovery from drought in these two species.

\section{Materials and methods}

\section{$106 \quad$ Plant material and experimental setup}

107 The experiments were carried out in two species: one angiosperm, Prunus lusitanica L. and one 108 conifer, Pseudotsuga menziesii M., a shrub and a tree respectively, selected for their contrasted PLC 109 thresholds of drought-induced mortality (i.e. $P_{88}$ and $P_{50}$ respectively). For each species, eight young 110 trees were grown under non-limiting water conditions in 5 and 9.2-L pots, respectively, at the INRAE111 PIAF research station of Clermont-Ferrand, France $\left(45877^{\circ} \mathrm{N}, 3814^{\circ} \mathrm{E}\right)$. P. menziesii individuals were 112 four years old at the time of the experiment while the $P$. lusitanica were two years old. Two weeks 113 before starting the experiment, all trees were moved to a controlled-environment glasshouse cell and 114 kept under natural light and at a mean temperature of $17.7 \pm 0.2^{\circ} \mathrm{C}$ (midday) and $10.9 \pm 0.1{ }^{\circ} \mathrm{C}$ (night). 115 During this period, trees were kept well-irrigated (field capacity) by a drip irrigation system controlled 116 by an electronic timer. After the two weeks of acclimation, a sub-set of trees for each species (from four 117 to six individuals) was exposed to progressive dehydration by withholding the irrigation. In order to 118 determine the critical PLC for recovery and because Hammond et al. (2019) reported that conifers were 119 able to recover even beyond $P_{50}$, trees were re-watered to field capacity once reaching water potential 120 values corresponding to significant losses in hydraulic functioning according to their vulnerabilities to 121 cavitation (i.e. PLC $>50 \%$ for conifers and PLC> 90\% for angiosperms). They were then kept well122 irrigated in order to check for recovery from drought.

Vulnerability curves to cavitation

Prior to the experiment, the vulnerability to cavitation for the two target species was determined to define when trees should be re-watered according to their PLC level. Thus, two different techniques 126 (i.e. one technique per species), reported as highly comparable by Brodribb et al. (2017), were used 127 according to the xylem characteristics of each species. Thus, for $P$. lusitanica, xylem vulnerability to 128 cavitation was determined by using the recently developed optical method (Brodribb et al. 2017) to 129 avoid possible biased results related with the open-vessel artefact (Torres-Ruiz et al. 2014, 2015, Choat 130 et al. 2016). Indeed, the use of the Cavitron method in this species was not possible due to the length of 131 the xylem conduits that were longer than the diameter of the rotor available (Sergent et al. 2020). For $P$. 132 menziesii, vulnerability curves were constructed by using the Cavitron technique (Cochard 2002) which 133 is highly reliable when used to measure species with short conduits such as conifers (Cochard et al. 134 2013, Torres-Ruiz et al. 2017). The use of the optical method was not possible for P. menziesii because 135 the conduits at the stem level are so short that the cavitation events are not always detectable. 
Briefly, for $P$. lusitanica, the entire plant was let to dehydrate under lab conditions while a clamp equipped with a camera was installed in the stem of four trees after removing the bark carefully with a razor blade to expose undamaged xylem. To avoid the over desiccation of the exposed xylem area during the $6.51 \pm 0.52$ days of dehydration, we applied a thin coat of silicone grease. The camera then captured images every five min during the dehydration process while changes in stem water potential $\left(\Psi_{\text {stem }}, \mathrm{MPa}\right)$ were continuously monitored using a psychrometer (PSY1, ICT international, Armidale, Australia) installed centrally on the main stem of each plant. The Peltier cooling time was adjusted from $10 \mathrm{~s}$ (when

143 the plant was well hydrated) to a maximum of $20 \mathrm{~s}$ (as the plant dehydrated) to ensure that sufficient 144 water was condensed onto the thermocouple and then evaporated to produce a stable reading of the wet145 bulb depression temperature. To ensure the accuracy of the measurements obtained with the 146 psychrometer, regular $\Psi_{\text {stem }}$ measurements were carried using a Scholander-type pressure chamber 147 (PMS, Corvallis) in fully developed and healthy leaves previously bagged for at least one hour to prevent 148 transpiration and promote equilibrium with the plant axis (Fig. S1). Image sequences were then analysed 149 manually according to Brodribb et al. (2016, 2017). The percentage of embolised pixels for each image 150 was calculated as the amount of embolised pixels cumulated and the total embolised area of the scanned 151 area. The vulnerability curve was obtained by plotting $\Psi_{\text {stem }}$ against cumulative embolisms (\% of total).

For P. menziesii, xylem vulnerability to cavitation was assessed with the Cavitron technique 153 (Cochard 2002) which uses centrifugal force to increase the water tension in a xylem segment while 154 measuring the decrease in its hydraulic conductance. Thus, five $0.45 \mathrm{~m}$-long stem samples from five 155 different well-hydrated trees (i.e. one sample per tree), were debarked to prevent resin contamination 156 and recut under water with a razor blade to a standard length of $0.27 \mathrm{~m}$. For constructing the vulnerability 157 curves, the maximum sample conductivity $\left(K_{\max }\right)$ was measured at low speed and relatively high xylem 158 pressure $(-0.75 \mathrm{MPa})$. The xylem pressure was then decreased stepwise by increasing the rotational 159 velocity and the conductivity $(K)$ measured at each pressure step. Each pressure was applied on the 160 sample for two minutes. Sample loss of conductivity (PLC, \%) was computed at each pressure as 161 follows:

$$
P L C=100 *\left(1-\frac{K}{K \max }\right)(1)
$$

163 The resulting curves were fitted according to Pammenter and Vander Willigen equation (1998) and 164 using the $\mathrm{R}$ 'fitPLC' package:

$$
\text { PLC or Cumulative embolism }=\frac{100}{\left(1+e^{(a / 25(P-P 50)}\right)}(2)
$$

166 where $a$ is the slope of the curve at the inflexion point, $P$ indicates the xylem water potential for the 167 optical method (P. lusitanica) or the target pressure reached with the Cavitron (P. menziesii), and $P_{50}$ is 
168 the $\Psi_{\text {stem }}$ or pressure value at which $50 \%$ of the xylem cavitation events had been observed or at which

$16950 \%$ loss of conductivity occurred.

170 Physiological traits

171 During the progressive dehydration imposed to each subset of plants, $\Psi_{\text {stem }}$ was continuously 172 assessed by using psychrometers (PSY1, ICT international). Thus, one psychrometer per plant in a total 173 of four plants per species was installed at the stem level and covered with aluminium foil to prevent 174 their direct exposure to the sunlight and minimize any effect of external temperature variations 175 (Vandegehuchte et al. 2014). Psychrometers recorded the $\Psi_{\text {stem }}$ every $30 \mathrm{~min}$. To check the accuracy of 176 the psychrometers, regular $\Psi_{\text {stem }}$ measurements were carried using a Scholander-type pressure chamber 177 (PMS, Corvallis) in two fully developed and healthy leaves per plant, previously bagged for at least one 178 hour to prevent transpiration and promote equilibrium with the plant axis (Fig. S1).

Stem diameter variations were monitored continuously by Linear Variable Differential 180 Transformer (LVDT) sensors (one LVDT per plant in eight plants per species) installed before 181 withholding irrigation. The sensor was applied on the stem with glue and was connected to a data logger 182 (Model CR1000, Campbell Scientific LTD) to collect the stem diameter variations (in $\mu \mathrm{m}$ ) every 10 183 min. By evaluating the dynamics of stem diameter during the dehydration and recovery phases of the 184 experiment, we were able to evaluate the capacity of the trees to recover from drought (Lamacque et al. 185 2020).

186 The RWC was measured at stem $\left(\mathrm{RWC}_{\text {Stem }}\right)$ and leaf level $\left(\mathrm{RWC}_{\text {Leaf }}\right)$ in all trees before 187 withholding irrigation (Control) and right before re-watering. $\mathrm{RWC}_{\text {Stem }}$ and $\mathrm{RWC}_{\mathrm{Leaf}}$ were calculated 188 according to Barrs and Weatherley (1962):

$$
R W C=\frac{(F W-D W)}{(T W-D W)}(3),
$$

190 where FW is the fresh weight measured immediately after sampling; TW is the turgid weight measured 191 after immersing the stem in distilled water for $24 \mathrm{~h}$ (for $\mathrm{RWC}_{\text {Stem }}$ ) or after soaking the leaf petiole for 24 192 hin distilled water (for $\mathrm{RWC}_{\text {Leaf }}$ ); and DW is the dry weight of the samples after $24 \mathrm{~h}$ of drying in an 193 oven at $72^{\circ} \mathrm{C}$. All measurements were done using a precision scale (METTLER AE 260, DeltaRange 194 (B) and were performed on three healthy leaves or one to three small stem sections per plant (depending 195 on plant material).

196 Once the trees reached water potentials corresponding to a PLC of ca. $88 \%$ for P. lusitanica and $19750 \%$ for P. menziesii according to the vulnerability curves, the PLC was assessed in stems using two 198 different, but comparable, techniques (Cochard 1992, Torres-Ruiz et al. 2014, Choat et al. 2016). For $P$. 199 lusitanica, PLC was determined gravimetrically using a xylem embolism meter (XYL'EM, Bronkhorst). 200 For $P$. menziesii, as it was impossible to restore the maximal conductance $\left(K_{\max }\right)$ due to the permanent 
201 aspiration of the pit membrane against the cell walls (Cochard et al. 2013), the PLC was assessed by 202 direct observation using X-Ray microtomography (Micro-CT, Nanotom $180 \mathrm{XS}$; GE) at the PIAF 203 laboratory (INRAE) (Cochard et al. 2015). For both techniques, samples were cut progressively 204 underwater to prevent artefactual increases in the amount of embolism in the samples (Torres-Ruiz et 205 al. 2015).

For the XYL'EM, the PLC was evaluated in three stems (sample length ca. 30mm) per 207 individual in eight individuals per species. The initial $K\left(K_{\mathrm{i}}\right)$ of each segment was determined using a 208 filtered $(0.22 \mu \mathrm{m}) 10 \mathrm{~mm} \mathrm{KCl}$ and $1 \mathrm{~mm} \mathrm{CaCl} 2$ perfusion solution made with distilled water (Cochard 209 et al. 2009), and applying a pressure head of $8.5 \mathrm{kPa}$ until a steady-state $K_{\mathrm{i}}$ was attained. In order to determine the maximal conductance $\left(K_{\max }\right)$, samples from $P$. lusitanica were flushed with water at high pressure $(200 \mathrm{kPa})$ for 20 minutes to remove all the embolism. PLC was then calculated using the 212 following equation:

$$
P L C=100 *\left(1-\frac{K i}{K \max }\right)
$$

For Micro-CT, one or two samples per plant were collected, as described for the gravimetric $K$ 215 measurements, and immediately immersed in liquid paraffin wax to prevent dehydration during the 216 scanning. For each 21 -min scan, 1000 images were recorded during the $360^{\circ}$ rotation of the sample. The 217 X-ray setup was fixed at $70 \mathrm{kV}$ and $240 \mu \mathrm{A}$. At the end of the experiment, samples were cut $3 \mathrm{~mm}$ above 218 the scanned cross-section, injected with air $(0.1 \mathrm{MPa})$ and re-scanned to visualize all the conduits filled 219 with air. The amount of PLC was computed by determining the ratio between the amount of cavitated 220 conduits in the samples before and after cutting the sample.

\section{$221 \quad$ Cell vitality}

Cell vitality was assessed using two different methods: the electrolytes leakage test (EL) (Zhang and Willison 1987, Sutinen et al. 1992) and a fluorescein diacetate (FDA) staining process (Widholm 224 1972). Cell vitality was assessed in both control and drying trees right before rewatering the latter ones. 225 For EL, one to three stem samples per plant (depending on plant material availability) were cut into ten $2262-\mathrm{mm}$ thick slices and immersed in test tubes containing $15 \mathrm{~mL}$ of pure water. Test tubes were shaken at 22760 shakes per min during $24 \mathrm{~h}$ at $5^{\circ} \mathrm{C}$ to stop enzyme activity. Water conductivity of the effusate $(\mathrm{C} 1)$ 228 was then measured at room temperature using a conductimeter (3310 SET1, Tetracon ${ }^{\circledR} 325$, WTW, 229 Weilheim, Germany). Then, all the living cells were killed by autoclaving the samples at $121^{\circ} \mathrm{C}$ for 30 $230 \mathrm{~min}$ (King and Ludford 1983), cooled down at room temperature $\left(22^{\circ} \mathrm{C}\right.$ approx.) for $60 \mathrm{~min}$ and the 231 effusate maximal conductivity (C2) measured. The lysis percentage (EL) was then determined as:

$$
E L=\frac{C 1}{C 2} * 100(5)
$$


To stain the cytoplasm of stem living cells and quantify the amount of living cells and their 234 location for each individual, FDA (F7378-10G, SIGMA-ALDRICH) was used. For this, two or three 60 $235 \mu \mathrm{m}$-thick stem cross-sections were obtained with a microtome (Leica RM2165) and stained for $20 \mathrm{~min}$ 236 in a 1\% FDA solution (Widholm 1972). Cross-sections were observed using an inverted fluorescence 237 microscope (Axio Observer Z1, ZEISS; Bright light or YFP filter) within the next hour after staining. 238 An entire cross-section image was obtained by joining images with the same magnification taken from 239 all the cross-section of the sample for both bright light and fluorescence observations. The percentage 240 of bark living cells (BLC) for each cross-section was calculated as follow:

$$
B L C=\frac{F A}{B A} * 100(6)
$$

242 Where FA is the total fluorescent area of the sample and BA is the bark area determined using Fiji 243 software (Schindelin et al. 2012).

\section{Statistical analyses}

Statistical analyses consisted of paired $t$-test (after testing for normality and homogeneity of variances) and Wilcoxon test (for non-normal distribution) and were performed using $\mathrm{R}$ programs to compare the set before the drought event (Control) and before re-watering. All tests were performed 248 using a level of significance $\alpha=0.05$.

\section{Results}

\section{Capacity of recovery from drought}

Vulnerability curves reported $P_{50}$-values of -6.07 and $-3.73 \mathrm{MPa}$ for $P$. lusitanica and $P$. 252 menziesii, respectively (Fig. 1). P. lusitanica individuals were thus rehydrated once they reached water 253 potential values of ca. -9.0 to $-10.0 \mathrm{MPa}$ i.e. above its $P_{88}$ of $-8.94 \mathrm{MPa}$. $P$. menziesii were rehydrated 254 once showing water potential of ca. -7.0 to $-10.0 \mathrm{MPa}\left(P_{88}=-5.34 \mathrm{MPa}\right)$.

In control conditions, the mean levels of PLC in the stem for P. lusitanica and P. menziesii were 6.9 ( $\pm 3.5 \mathrm{SE}$ ) and 7.40 ( $\pm 2.8 \mathrm{SE})$ respectively (Fig. 2). Right before applying the recovery irrigation, the mean PLC for P. lusitanica and P. menziesii were $94.4( \pm 1.98 \mathrm{SE})$ and $79.5( \pm 3.7 \mathrm{SE})$ respectively 258 (Table S1) i.e. above the current point for xylem hydraulic failure for angiosperms (i.e. $P_{88}$ ) and conifers 259 (i.e. $\left.P_{50}\right)$.

Stems showed a noticeable shrinkage for both species during the time-course of the dehydration 261 for all individuals (Fig. 3). After rewatering, two P. lusitanica individuals that reached a mean PLC of 26290.3 ( $\pm 8.3 \mathrm{SE}$ ) (Fig. 2A) showed an increase in stem diameter immediately after being re-hydrated and were considered as recovered trees (Fig. 3A). On the contrary, the six individuals that reached PLC of $95.8( \pm 1.1 \mathrm{SE})$ showed a continuous decrease in stem diameter after the rehydration and were considered 
265 as dead trees (Fig. 3C). For P. menziesii, only one individual that reached a $\Psi_{\text {stem }}$ value of -7.48MPa and 266 a PLC level of 67.9 (Fig. 2B) was able to recover in terms of trunk diameter after rewatering (Fig. 3B). 267 All the other individuals continued to show a decrease in stem diameter during the re-watering phase 268 after reaching a mean $\Psi_{\text {stem }}$ value of $-8.7 \mathrm{MPa}( \pm 0.5 \mathrm{SE})$ (Fig. 3D) and a mean PLC of $81.1( \pm 3.8 \mathrm{SE})$ 269 (Fig. 2B).

For both species, individuals that were able to recover from drought showed an increase in $\Psi_{\text {stem }}$ concomitantly to the increase in stem diameter (Fig. 3A, B) while no recovery in $\Psi_{\text {stem }}$ was noticed in trees considered as dead (Fig. 3C and Fig. 3D).

A significant decrease in $\mathrm{RWC}_{\text {Stem }}$ was observed for both species during dehydration as PLC increases (Fig. 4A and Fig. 4B; Table S2). In control P. lusitanica trees, $\mathrm{RWC}_{\text {Stem }}$ was of $92.3 \%( \pm 0.8$ $\mathrm{SE})$ whereas it dropped for those exposed to drought to $58.5 \%( \pm 1.5 \mathrm{SE})$ for recovered individuals and to $54.7 \%$ ( $\pm 3.6 \mathrm{SE})$ for dead individuals before re-watering. Differences in $\mathrm{RWC}_{\text {Stem }}$, however, were not significant when comparing recovered and dead individuals. Similar results were observed for $P$. menziesii, with a significant decrease in $\mathrm{RWC}_{\text {Stem }}$ noticed for both recovered and dead individuals from drought. Thus, $\mathrm{RWC}_{\mathrm{Stem}}$ decreased from $83.4 \%$ ( $\left.\pm 1.1 \mathrm{SE}\right)$ for control trees to $49.8 \%$ for recovered and $36.9 \%( \pm 1.9 \mathrm{SE})$ for dead trees.

Similar to $\mathrm{RWC}_{\text {Stem }}, \mathrm{RWC}_{\text {Leaf }}$ was significantly impacted in both species during dehydration (Fig. 4C, D; Table S2). For P. lusitanica, $\mathrm{RWC}_{\text {Leaf }}$ decreased from $94.8 \%$ ( $\pm 0.5 \mathrm{SE}$ ) (Control) to $56.9 \%$ ( $\pm 4.1 \mathrm{SE})$ in plants that recovered from drought and to $59.3 \%( \pm 4.8 \mathrm{SE})$ in those that did not recover. For P. menziesii, $\mathrm{RWC}_{\text {Leaf }}$ went from $92.4 \%( \pm 2.0 \mathrm{SE})$ (Control) to $53.5 \%$ in recovered trees or 51.5 $\%( \pm 4.7 \mathrm{SE})$ in dead trees. Differences in $\mathrm{RWC}_{\text {Leaf }}$ were not significant for any of the two species when comparing recovered and dead individuals.

\section{Tissue vitality}

For $P$. lusitanica, all trees showed higher EL values than control ones before re-watering (Fig. 4E and Fig. 4F, Table S2) (Control: 29.9\% 1.3 SE; Recovered: 47.12\% \pm 7.12 SE; Dead: $57.2 \% \pm 6.7$ SE). However, no differences were noticed when comparing recovered and dead individuals before rewatering (Recovered: $47.1 \% \pm 7.1 \mathrm{SE}$; Dead: $57.2 \% \pm 6.7 \mathrm{SE}$ ). For, P. menziesii, only the trees that did not recover showed higher EL values compared to control (Control: $50.6 \% \pm 2.2$ SE; Dead: $78.8 \% \pm 2.2$ SE). No differences in EL were observed between the recovered individual and control ones (Control: $50.6 \% \pm 2.2$ SE; Recovered: $50.8 \%$ ). The recovered individual tends to show lower EL values than the dead ones (Recovered: 50.8\%; Dead: 78.8\% $\pm 1.2 \mathrm{SE}$ ).

In control trees and for both species, the FDA staining showed that living cells were mostly located at the outer bark and phloem level (Fig. 5). Before re-watering, the amount of living cells in $P$. lusitanica decreased noticeably in dead trees (Fig. 6A; Table S3) (Control: 23.0\% \pm 4.4 SE; Dead: 3.0\% 

$\pm 1.4 \mathrm{SE}$ ) but not in trees that recovered (Control: $23.0 \% \pm 2.4 \mathrm{SE}$; Recovered: $15.3 \% \pm 10.4 \mathrm{SE}$ ). For $P$. menziesii, the amount of living cells decreased in trees that did not recover (Control: 10.2\% $\pm 2.1 \mathrm{SE}$; Dead: $0.8 \% \pm 0.6 \mathrm{SE}$ ) while no noticeable decrease was encountered in trees that recovered (Control: $10.2 \% \pm 2.2$ SE; R: 7.2\%) (Fig. 6B; Table S3).

\section{Discussion}

Our results provide strong evidence that even when presenting high levels of hydraulic dysfunction, trees were able to recover from an extreme drought event after being re-watered. Indeed, $P$. lusitanica individuals that showed PLC values of $98.6 \%$, i.e. well above the suggested threshold for recovery and point of death for angiosperms ( $P_{88}$, Barigah et al. 2013; Urli et al. 2013), recovered from drought according to their stem diameter dynamic (i.e. showed an increase in stem diameter immediately after re-watering) and even flushed new leaves after being re-watered at field capacity (Fig. S2). Similarly, $P$. menziesii individuals with PLC values of $67.9 \%$, i.e. above the threshold for recovery for conifers $\left(P_{50}\right.$, Brodribb and Cochard 2009), were also able to recover once re-watered. These results, therefore, demonstrate how trees are able to recover from drought even when their PLC levels reach higher values than those considered as threshold for recovery for angiosperms and conifers (i.e. $P_{88}$ and $P_{50}$, respectively). These results agree with those provided for loblolly pine (Pinus taeda L.) by Hammond et al. (2019) which reported a higher chance for trees to die than to survive once reaching PLC levels of 80 , i.e. much higher than the $P_{50}$ threshold commonly reported for conifers. In our study, however, no recovery was observed for $P$. menziesii when PLC reached values above $68 \%$, which raises questions on how lethal PLC thresholds vary among tree species. For angiosperms, our results also agree with the ones provided for Pistacia lentiscus L. by Vilagrosa et al. (2003) that show how droughtinduced mortality only occur in plants that reached PLC values of almost $100 \%$. When taken together, all these results highlight the importance of revising the actual recovery and point of death thresholds suggested for angiosperms and conifers. More importantly, these results show that plant mortality occurs when the losses in xylem conductance are important (e.g. $>90 \%$ of xylem hydraulic dysfunction), suggesting that PLC is not the sole triggering mechanism of plant death under drought conditions.

Unfortunately, any critical thresholds for most of the physiological traits monitored during our experiment were identified as a potential proxy for drought-induced mortality. Thus, it was not possible to evince a clear causal link between stem hydraulic failure and plant mortality since trees that were not able to recover from drought did not consistently show higher PLC values than those that survived. However, two interesting trends emerged from the $\mathrm{RWC}_{\mathrm{Stem}}$ and $\mathrm{EL}$ results for P. menziesii. On one hand, trees recovering from drought tend to show higher $\mathrm{RWC}_{\text {Stem }}$ than dead ones before re-watering and, on the other hand, trees that recovered tend to show lower EL values than the dead ones. These results agree with Martinez-Vilalta et al. (2019) and highlight the importance of plant water content as a potential indicator of mortality risk. However, this was not the case for $P$. lusitanica since similar 
$334 \mathrm{RWC}_{\text {Stem }}$ values were observed in both trees that were able to recover from drought and those that were 335 not. This raises the possibility of using $\mathrm{RWC}_{\mathrm{Stem}}$ as a proxy for mortality across species, although more 336 confirmatory studies should be carried out especially in angiosperms. At leaf level, $\mathrm{RWC}_{\text {Leaf }}$ at turgor 337 loss point is relatively high and constant between species (Bartlett et al. 2012), which potentially could 338 make it a useful trait for identifying survival events since noticeable changes in $\mathrm{RWC}_{\text {Leaf }}$ would occur 339 at high dehydration level preceding death (Martinez-Vilalta et al. 2019). However, no differences in $340 \mathrm{RWC}_{\mathrm{Leaf}}$ were detected in our study between recovering and dead trees before re-watering for any of the 341 two species evaluated probably because, at those levels of water stress, leaves were already hydraulically 342 disconnected from the stems in all the individuals. This would favour a faster dehydration of the leaves 343 in comparison with the stems and, therefore, may partially explain the similarly low values for $\mathrm{RWC}_{\text {Leaf }}$. 344 Therefore, rather than just focusing only on the plant water status, a deeper study on water relocation in 345 trees during drought (Körner 2019) would be required for identifying potential proxies for drought346 induced mortality. In fact, a crucial question now is to evaluate if the relocation of water from plant 347 reserves would be enough for keeping key tree tissues hydrated during drought and, therefore, enhancing 348 plant probability of survival after re-watering (Holbrook 1995).

349 Regarding cell integrity, recovering trees from drought tend to present lower cell damages than 350 the dead trees before re-watering. P. menziesii recovering trees showed seemingly no changes in their 351 percentage of EL even after the drought event. Dead trees, on the contrary, consistently showed higher 352 EL values before re-watering than control trees able to recover in agreement with the results reported 353 by Vilagrosa et al. (2010) for P. lentiscus. Even if $P$. lusitanica dead and recovering trees did not show 354 any differences in EL, recovering trees were able to resprout and flush new leaves when the stress was 355 alleviated (Fig. S2). As higher EL values are the consequences of membrane failure and are associated 356 with cell death (Vilagrosa et al. 2010, Guadagno et al. 2017), these observations suggest that the fatal 357 failure at the cellular scale does not occur homogeneously within the stem and this, as shown by Thomas 358 (2013) and Klimešová et al. (2015), allow the resprouting of the plant if the stress is relieved. Therefore, 359 according to our results, the membrane integrity could emerge as a proxy for lack of recovery capacity 360 in conifers since the cell vitality in some of the living tissues at the stem level seems to have a relevant 361 role in drought-induced mortality. However, the link between membrane failure and the loss in stem 362 hydraulic functioning is still unresolved. Indeed, it is still unclear whether the extreme dehydration leads 363 to membrane failure through physical (i.e. cell cavitation, Sakes et al. 2016), collapse and cytorrhysis 364 (Taiz and Zeiger 2006) or only biochemical processes (Suzuki et al. 2012, Wang et al. 2013, Petrov et 365 al. 2015).

366 The presence of living cells in stems at the inner bark level was not always related to the survival 367 of the trees after re-watering (i.e. increase in stem diameter). This was the case for P. lusitanica where 368 trees showing similar amounts of living cells, differed in their capacity to recover from drought. The 369 presence of living cells in dead trees could be explained by the fact that, under drought conditions, trees 
370 can rely on their own water reserves (Epila et al. 2017) which could temporally maintain the metabolism 371 of the cell despite being hydraulically disconnected from the roots. However, once the water reserves 372 are depleted, living tissues would ultimately dry and cells would dehydrate and die. Therefore, not only 373 the presence of living cells is required for allowing the plant to recover from drought but also their 374 hydraulic connection with the other plant tissues and organs upstream. Thus, even at stem PLC values 375 near to $100 \%$ for angiosperms or well above $50 \%$ for conifers, a minimal hydraulic connection between 376 the soil and the living tissues could be enough to recover from drought if plants have access to water. 377 More studies focused on the link between xylem hydraulic functioning, plant capacitance and cell 378 mortality are therefore required to identify what the thresholds for tree survival to drought are.

\section{Conclusion}

380 By combining a living-cell staining process with LVDT sensors and PLC measurements, this 381 study showed that the common thresholds for recovery and point of death considered until now, i.e $P_{50}$ 382 for conifers and $P_{88}$ for angiosperms, are not accurate enough for assessing and predicting drought383 induced tree mortality. Indeed, our results showed that trees with PLC levels of $98.6 \%$ for $P$. lusitanica 384 (angiosperm) and $67.9 \%$ for P. menziesii (conifer) were still able to recover from drought once re385 watered. Thus, even if the link between a high level of stem PLC and tree mortality is clear, there is an 386 urgent need in defining new physiological thresholds for predicting tree mortality with mechanistic 387 models. For conifers, higher $\mathrm{RWC}_{\text {Stem }}$ and lower EL values were related to a higher capacity to survive 388 drought. However, this was not the case for angiosperms for which no physiological traits were 389 identified as a potential proxy for the capacity of plant to recover although a similar pattern as to the one 390 observed for the conifer species was identified.

\section{Author contributions}

392 MM and JMTR conceived and designed the experiment. MM and PEMS were responsible for 393 running the measurements and carried out the data analysis. EB supervised the setting up of the micro394 CT scans. MM, PEMS, HC and JMTR interpreted the results. MM wrote the first manuscript draft. 395 JMTR, PEMS, HC and EB assisted substantially with manuscript development.

\section{Acknowledgement}

397 The authors thank Pierre Conchon and Julien Cartailler for their technical assistance, and the 398 PIAF Research Unit staff for their support during this experiment. This research was funded by the 399 project ANR-18-CE20-0005 Hydrauleaks.

\section{$400 \quad$ Data availability statement}

401 The data are not publicly available due to privacy restrictions. 402 


\section{References}

406 Adams HD, Zeppel MJB, Anderegg WRL, Hartmann H, Landhäusser SM, Tissue DT, Huxman TE, 407 Hudson PJ, Franz TE, Allen CD, Anderegg LDL, Barron-Gafford GA, Beerling DJ, Breshears DD, 408 Brodribb TJ, Bugmann H, Cobb RC, Collins AD, Dickman LT, Duan H, Ewers BE, Galiano L, 409 Galvez DA, Garcia-Forner N, Gaylord ML, Germino MJ, Gessler A, Hacke UG, Hakamada R, 410 Hector A, Jenkins MW, Kane JM, Kolb TE, Law DJ, Lewis JD, Limousin JM, Love DM, Macalady 411 AK, Martínez-Vilalta J, Mencuccini M, Mitchell PJ, Muss JD, O’Brien MJ, O’Grady AP, Pangle 412 RE, Pinkard EA, Piper FI, Plaut JA, Pockman WT, Quirk J, Reinhardt K, Ripullone F, Ryan MG, 413 Sala A, Sevanto S, Sperry JS, Vargas R, Vennetier M, Way DA, Xu C, Yepez EA, McDowell NG 414 (2017) A multi-species synthesis of physiological mechanisms in drought-induced tree mortality. $415 \quad$ Nat Ecol Evol 1:1285-1291. http://dx.doi.org/10.1038/s41559-017-0248-x

416 Allen CD, Macalady AK, Chenchouni H, Bachelet D, McDowell N, Vennetier M, Kitzberger T, Rigling 417 A, Breshears DD, Hogg EH (Ted., Gonzalez P, Fensham R, Zhang Z, Castro J, Demidova N, Lim 418 JH, Allard G, Running SW, Semerci A, Cobb N (2010) A global overview of drought and heat419 induced tree mortality reveals emerging climate change risks for forests. For Ecol Manage 259:660-684.

421 Barigah TS, Charrier O, Douris M, Bonhomme M, Herbette S, Améglio T, Fichot R, Brignolas F, 422 Cochard H (2013) Water stress-induced xylem hydraulic failure is a causal factor of tree mortality 423 in beech and poplar. Ann Bot 112:1431-1437.

424 Barrs H., Weatherley PE (1962) A Re-Examination of the Relative Turgidity Techniques for Estimating $425 \quad$ Water Deficits in Leaves. Aust J Biol Sci 15:413-428.

426 Bartlett MK, Scaffoni C, Sack L (2012) The determinants of leaf turgor loss point and prediction of 427 drought tolerance of species and biomes : a global meta-analysis. Ecol Lett 15:393-405.

428 Berry JA, Beerling DJ, Franks PJ (2010) Stomata: Key players in the earth system, past and present. 429 Curr Opin Plant Biol 13:233-240. http://dx.doi.org/10.1016/j.pbi.2010.04.013

430 Bolte A, Czajkowski T, Cocozza C, Tognetti R, De Miguel M, Pšidová E, Ditmarová L, Dinca L, Delzon 431 S, Cochard H, Ræbild A, De Luis M, Cvjetkovic B, Heiri C, Müller J (2016) Desiccation and 432 mortality dynamics in seedlings of different European beech (Fagus sylvatica L.) populations 433 under extreme drought conditions. Front Plant Sci 7:1-12.

434 Brodribb TJ, Bowman DJMS, Nichols S, Delzon S, Burlett R (2010) Xylem function and growth rate 435 interact to determine recovery rates after exposure to extreme water deficit. New Phytol 188:533436542.

437 Brodribb TJ, Carriqui M, Delzon S, Lucani C (2017) Optical Measurement of Stem Xylem 
Vulnerability. Plant Physiol 174:2054-2061.

439

440

441

442

443

444

445

446

447

448

449

450

451

452

453

454

455

456

457

458

459

460

461

462

463

464

465

466

467

468

Brodribb TJ, Cochard H (2009) Hydraulic Failure Defines the Recovery and Point of Death in Water$\begin{array}{llll}\text { Stressed } & \text { Conifers. Plant } & \text { Physiol }\end{array}$ http://www.plantphysiol.org/cgi/doi/10.1104/pp.108.129783

Brodribb TJ, Skelton RP, Mcadam SAM, Bienaimé D, Lucani CJ, Marmottant P (2016) Visual quantification of embolism reveals leaf vulnerability to hydraulic failure. New Phytol 209:14031409.

Buckley T (2005) The control of stomata by water balance. New Phytol:275-292.

Chaturvedi AK, Patel MK, Mishra A, Tiwari V, Jha B (2014) The SbMT-2 Gene from a Halophyte Confers Abiotic Stress Tolerance and Modulates ROS Scavenging in Transgenic Tobacco. 9

Choat B, Badel E, Burlett R, Delzon S, Cochard H, Jansen S (2016) Noninvasive Measurement of Vulnerability to Drought-Induced Embolism by X-Ray Microtomography. Plant Physiol 170:273282. http://www.plantphysiol.org/lookup/doi/10.1104/pp.15.00732

Choat B, Brodribb TJ, Brodersen CR, Duursma RA, López R, Medlyn BE (2018) Triggers of tree mortality under drought. Nature 558:531-539. https://doi.org/10.1038/s41586-018-0240-x

Choat B, Jansen S, Brodribb TJ, Cochard H, Delzon S, Bhaskar R, Bucci SJ, Feild TS, Gleason SM, Hacke UG, Jacobsen AL, Lens F, Maherali H, Martínez-Vilalta J, Mayr S, Mencuccini M, Mitchell PJ, Nardini A, Pittermann J, Pratt RB, Sperry JS, Westoby M, Wright IJ, Zanne AE (2012) Global convergence in the vulnerability of forests to drought. Nature 491:752-755.

Cochard H (1992) Vulnerability of several conifers to air embolism. Tree Physiol 11:73-83.

Cochard H (2002) A technique for measuring xylem hydraulic conductance under high negative pressures. Plant, Cell Environ 25:815-819.

Cochard H, Badel E, Herbette S, Delzon S, Choat B, Jansen S (2013) Methods for measuring plant vulnerability to cavitation: A critical review. J Exp Bot 64:4779-4791.

Cochard H, Delzon S, Badel E (2015) X-ray microtomography (micro-CT): A reference technology for high-resolution quantification of xylem embolism in trees. Plant, Cell Environ 38:201-206.

Cochard H, Herbette S, Hernández E, Hölttä T, Mencuccini M (2009) The effects of sap ionic composition on xylem vulnerability to cavitation. J Exp Bot 61:275-285.

Creek D, Lamarque LJ, Torres-Ruiz JM, Parise C, Burlett R, Tissue DT, Delzon S (2020) Xylem embolism in leaves does not occur with open stomata: evidence from direct observations using the optical visualization technique. J Exp Bot 71:1151-1159. 
Delzon S, Cochard H (2014) Recent advances in tree hydraulics highlight the ecological significance of the hydraulic safety margin. New Phytol 203:355-358.

471 Delzon S, Douthe C, Sala A, Cochard H (2010) Mechanism of water-stress induced cavitation in 472 conifers: Bordered pit structure and function support the hypothesis of seal capillary-seeding. Plant, Cell Environ 33:2101-2111.

Duan H, Duursma RA, Huang G, Smith RA, Choat B, O'Grady AP, Tissue DT (2014) Elevated [CO2] does not ameliorate the negative effects of elevated temperature on drought-induced mortality in Eucalyptus radiata seedlings. Plant, Cell Environ 37:1598-1613.

Epila J, De Baerdemaeker NJF, Vergeynst LL, Maes WH, Beeckman H, Steppe K (2017) Capacitive water release and internal leaf water relocation delay drought-induced cavitation in African Maesopsis eminii. Tree Physiol 37:481-490.

FAO (2006) Global forest resources assessment 2005-progress towards sustainable forest management. FAO For Pap 147

Guadagno CR, Ewers BE, Speckman HN, Aston TL, Huhn BJ, DeVore SB, Ladwig JT, Strawn RN, Weinig C (2017) Dead or alive? Using membrane failure and chlorophyll fluorescence to predict mortality from drought. Plant Physiol 175:pp.00581.2016. http://www.plantphysiol.org/lookup/doi/10.1104/pp.16.00581

Hacke UG, Venturas MD, Mackinnon ED, Jacobsen AL, Sperry JS, Pratt RB (2015) The standard centrifuge method accurately measures vulnerability curves of long-vesselled olive stems. New Phytol 205:116-127.

Hammond WM, Yu KL, Wilson LA, Will RE, Anderegg WRL, Adams HD (2019) Dead or dying? Quantifying the point of no return from hydraulic failure in drought-induced tree mortality. New Phytol:nph.15922. https://onlinelibrary.wiley.com/doi/abs/10.1111/nph.15922

Hogg EH, Hurdle PA (1997) Sap flow in trembling aspen implications for stomatal responses to VPD. Tree Physiol 17:501-509.

Holbrook NM (1995) Stem Water Storage. Plant Stems:151-174.

495 Hosking GP, Hutcheson JA (1988) Mountain beech (nothofagus solandri var. cliffortioides) decline in 496 the kaweka range, north island, new zealand. New Zeal J Bot 26:393-400.

497 Intergovernmental Panel on Climate Change (2014) Climate Change 2014: Synthesis Report; Chapter 498 Observed Changes and their Causes.

499 Keenan TF, Hollinger DY, Bohrer G, Dragoni D, Munger JW, Schmid HP, Richardson AD (2013) $500 \quad$ Increase in forest water-use efficiency as atmospheric carbon dioxide concentrations rise. Nature 
499:324-327.

502 King M., Ludford PM (1983) Chilling injury and electrolyte leakage in fruit of different tomato cultivars. J Am Soc Hort Sci 108:74-77.

504

505

506

507

508

509

510

511

512

513

514

515

516

517

518

519

520

521

522

523

524

525

526

527

528

529

530

531

Klimešová J, Nobis MP, Herben T (2015) Senescence, ageing and death of the whole plant: Morphological prerequisites and constraints of plant immortality. New Phytol 206:14-18.

Körner C (2019) No need for pipes when the well is dry - a comment on hydraulic failure in trees. Tree Physiol. https://academic.oup.com/treephys/advancearticle/doi/10.1093/treephys/tpz030/5425286

Lamacque L, Charrier G, dos Santos Farnese F, Lemaire B, Ameglio T, Herbette S (2020) Droughtinduced mortality: branch diameter variation reveals a point of no recovery in lavender species. Plant Physiol:pp.00165.2020.

Landmann G, Dreyer E (2006) Impacts of drought and heat on forest. Synthesis of available knowledge, with emphasis on the 2003 event in Europe. Ann For Sci 3 6:567-652.

Lwanga JS (2003) Localized tree mortality following the drought of 1999 at Ngogo, Kibale National Park, Uganda. Afr J Ecol 41:194-196.

Martin-StPaul N, Delzon S, Cochard H (2017) Plant resistance to drought depends on timely stomatal closure. Ecol Lett 20:1437-1447.

Martinez-Vilalta J, Anderegg WRL, Sapes G, Sala A (2019) Greater focus on water pools may improve our ability to understand and anticipate drought-induced mortality in plants. New Phytol

McDowell N, Pockman WT, Allen CD, Breashears DD, Cobb N, Kolb T, Plaut J, Sperry J, West A, Williams DG, Yepez EA (2008) Mechanisms of plants survival and mortality during drought: why do some plants survive while others succumb to drought? New Phytol 178:719-739.

Pammenter N., Vander Willigen C (1998) A mathematical and statistical analysis of the curves illustrating vulnerability of xylem to cavitation. Tree Physiol 18:589-593.

Petrov V, Hille J, Mueller-Roeber B, Gechev TS (2015) ROS-mediated abiotic stress-induced programmed cell death in plants. Front Plant Sci 6:1-16. http://journal.frontiersin.org/Article/10.3389/fpls.2015.00069/abstract

Reichstein M, Bahn M, Ciais P, Frank D, Mahecha MD, Seneviratne SI, Zscheischler J, Beer C, Buchmann N, Frank DC, Papale D, Rammig A, Smith P, Thonicke K, Van Der Velde M, Vicca S, Walz A, Wattenbach M (2013) Climate extremes and the carbon cycle. Nature 500:287-295. http://dx.doi.org/10.1038/nature12350 
532 Sakes A, Van Wiel M Der, Henselmans PWJ, Van Leeuwen JL, Dodou D, Breedveld P (2016) Shooting mechanisms in nature: A systematic review. PLoS One 11

534 Salmon Y, Torres-Ruiz JM, Poyatos R, Martinez-Vilalta J, Meir P, Cochard H, Mencuccini M (2015)

535

536

537

538

539

540

541

542

543

544

545

546

547

548

549

550

551

552

553

554

555

556

557

558

559

560

561

562

563 Balancing the risks of hydraulic failure and carbon starvation: A twig scale analysis in declining Scots pine. Plant Cell Environ 38:2575-2588.

Schindelin J, Arganda-Carreras I, Frise E, Kaynig V, Longair M, Pietzsch T, Preibisch S, Rueden C, Saalfeld S, Schmid B, Tinevez JY, White DJ, Hartenstein V, Eliceiri K, Tomancak P, Cardona A (2012) Fiji: An open-source platform for biological-image analysis. Nat Methods 9:676-682.

Sperry JS, Love DM (2015) What plant hydraulics can tell us about responses to climate-change droughts. New Phytol 207:14-27.

Sutinen M-L, Palta JP, Reich PB (1992) Seasonal differences in freezing stress resistance of needles of Pinus nigra and Pinus resinosa: evaluation of the electrolyte leakage method. Tree Physiol 11:241254. https://academic.oup.com/treephys/article-lookup/doi/10.1093/treephys/11.3.241 (1 April 2019, date last accessed ).

Suzuki N, Koussevitzky S, Mittler R, Miller G (2012) ROS and redox signalling in the response of plants to abiotic stress. Plant, Cell Environ 35:259-270.

Taiz L, Zeiger E (2006) Plant Physiology. In: Sinauer Associates I (ed) Fourth Edi.pp 46-47.

Thomas H (2013) Senescence, ageing and death of the whole plant. :696-711.

Torres-Ruiz JM, Cochard H, Choat B, Jansen S, López R, Tomášková I, Padilla-Díaz CM, Badel E, Burlett R, King A, Lenoir N, Martin-StPaul NK, Delzon S (2017) Xylem resistance to embolism: presenting a simple diagnostic test for the open vessel artefact. New Phytol 215:489-499.

Torres-Ruiz JM, Cochard H, Mayr S, Beikircher B, Diaz-Espejo A, Rodriguez-Dominguez CM, Badel E, Fernández JE (2014) Vulnerability to cavitation in Olea europaea current-year shoots: Further evidence of an open-vessel artifact associated with centrifuge and air-injection techniques. Physiol Plant 152:465-474.

Torres-Ruiz JM, Jansen S, Choat B, McElrone AJ, Cochard H, Brodribb TJ, Badel E, Burlett R, Bouche PS, Brodersen CR, Li S, Morris H, Delzon S (2015) Direct X-Ray Microtomography Observation Confirms the Induction of Embolism upon Xylem Cutting under Tension. Plant Physiol 167:4043. http://www.plantphysiol.org/lookup/doi/10.1104/pp.114.249706

Trueba S, Pan R, Scoffoni C, John GP, Davis SD, Sack L (2019) Thresholds for leaf damage due to dehydration: declines of hydraulic function, stomatal conductance and cellular integrity precede those for photochemistry. New Phytol 223:134-149. 
564 Trumbore S, Brando P, Hartmann H (2015) Forest health and global change. Science (80- ) 349:814$565 \quad 818$

566 Tyree MT, Zimmermann MH (2002) Xylem structure and the ascent of sap. Springer, New York, NY.

567 Urli M, Porté AJ, Cochard H, Guengant Y, Burlett R, Delzon S (2013) Xylem embolism threshold for 568 catastrophic hydraulic failure in angiosperm trees. Tree Physiol 33:672-683.

569 Vandegehuchte MW, Guyot A, Hubau M, De Groote SRE, De Baerdemaeker NJF, Hayes M, Welti N, 570 Lovelock CE, Lockington DA, Steppe K (2014) Long-term versus daily stem diameter variation 571 in co-occurring mangrove species: Environmental versus ecophysiological drivers. Agric For 572 Meteorol 192-193:51-58. http://dx.doi.org/10.1016/j.agrformet.2014.03.002

573 Vilagrosa A, Bellot J, Vallejo VR, Gil-Pelegrín E (2003) Cavitation, stomatal conductance, and leaf 574 dieback in seedlings of two co-occurring Mediterranean shrubs during an intense drought. J Exp $575 \quad$ Bot 54:2015-2024.

576 Vilagrosa A, Morales F, Abadía A, Bellot J, Cochard H, Gil-Pelegrin E (2010) Are symplast tolerance 577 to intense drought conditions and xylem vulnerability to cavitation coordinated? An integrated 578 analysis of photosynthetic, hydraulic and leaf level processes in two Mediterranean drought579 580 581 582 583 resistant species. Environ Exp Bot 69:233-242. http://dx.doi.org/10.1016/j.envexpbot.2010.04.013

Wang C-R, Yang A-F, Yue G-D, Gao Q, Yin H-Y, Zhang J-R (2008) Enhanced expression of phospholipase C 1 ( ZmPLC1) improves drought tolerance in transgenic maize. Planta 227:11271140.

584 Wang M, Zheng Q, Shen Q, Guo S (2013) The critical role of potassium in plant stress response. Int J $585 \quad$ Mol Sci 14:7370-7390.

586 Widholm J (1972) The use of FDA and phenosafranine for determining viability of cultured plant cells. $587 \quad$ Stain Technol 47:189-94.

588 Zhang MIN, Willison JHM (1987) An improved conductivity method for the measurement of frost 589 hardiness. Can J Bot 65:710-715. http://www.nrcresearchpress.com/doi/10.1139/b87-095 (1 April $590 \quad 2019$, date last accessed ).

\section{$591 \quad$ Supporting information}

592 Additional supporting information may be found online in the Supporting Information section at the end 593 of the article:

594 Table S1. PLC evolution during the time-course of the experiment. 
595 Table S2. Evolution of the stem relative water content $\left(\mathrm{RWC}_{\text {Stem }}\right)$, leaf relative water content $\left(\mathrm{RWC}_{\text {Leaf }}\right)$ 596 and electrolytes leakage (EL) during the time-course of the experiment

597 Table S3. Evolution of the percentage of bark living cells (\%BLC) during the time-course of the 598 experiment.

599 Figure S1. Validation of the $\Psi_{\text {stem }}$ measurements recorded with psychrometer and compared to the $\Psi_{\text {stem }}$ 600 measurements carried out with the Scholander pressure chamber on previously bagged leaves.

601 Figure S2. Plants flushing new leaves after re-watering.

\section{Figures legends}

603 Figure 1. Vulnerability curves to cavitation for $P$. lusitanica stems and $P$. menziesii stems. Vulnerability 604 curve for P. lusitanica stems obtained on four different samples using the optical method (Brodribb et 605 al. 2017). The $P_{50}$ is evaluated at $-6.07 \mathrm{MPa}$ while the $P_{88}$ is evaluated at $-8.94 \mathrm{MPa}$. Vulnerability curve 606 for P. menziesii stems obtained on five different samples using the Cavitron technique developed by 607 Cochard in 2002. The $P_{50}$ is evaluated at $-3.73 \mathrm{MPa}$ and $P_{88}$ is evaluated at $-5.34 \mathrm{MPa}$. Red solid lines 608 represent the $P_{50}$ while red dashed lines represent the confidence interval around $P_{50}$ at $95 \%$. Violet and 609 green rectangles correspond to the water potential values at which $P$. lusitanica and $P$. menziesii were respectively irrigated.

611 Figure 2. Box plots representing the dispersions of percentage loss of conductance (PLC) values for A 612 P. lusitanica and B P. menziesii before water stress (control) and before re-watering for recovering (R) 613 and dead (D) trees measured with the Xyl'EM apparatus for $P$. lusitanica and X-ray micro-CT for $P$. 614 menziesii.

615 Figure 3. Dynamic of the stem diameter (solid line) and evolution of the water potential (points) during 616 the time-course of the experiment. Stem diameter dynamic (in $\mu \mathrm{m}$ ) was recorded by Linear Variable 617 Differential Transformer (LVDT) for both species while the water potential was measured punctually 618 using a Scholander pressure chamber for $P$. lusitanica individuals and continuously by psychrometers 619 for $P$. menziesii individuals. The light grey rectangles represent the period where water was withheld to 620 simulate an extreme drought event. The red line indicates the percentage loss of conductance (PLC) 621 value at which the plant was re-watered. Panels A and B show the recovery of individuals after re622 watering in terms of stem diameter while panels $\mathrm{C}$ and $\mathrm{D}$ show dead individuals.

623 Figure 4. Variation of Stem Relative Water Content ( $\mathrm{RWC}_{\text {Stem }}$ ) (panels A and B), Leaf Relative Water 624 Content $\left(\mathrm{RWC}_{\text {Leaf }}\right.$ ) (panels C and D), stem Electrolyte Leakage (EL) (panels E and F) for P. lusitanica 625 and P. menziesii. Measurements were performed on all individuals in control conditions (Control) and 626 after the drought event (i.e. before the rehydration of the plants for recovered and dead individuals). 
627 Figure 5. Cross-sections of P. lusitanica (A and B) and P. menziesii (C and D) stems in control 628 conditions. Cross-sections were stained using fluorescein diacetate (FDA) $(60 \mu \mathrm{m}$ thick cross-section $6291 \%$ solution) and microphotographs were taken using a bright light (A and C) and an inverted 630 fluorescence microscope (YFP filter; B and D). Living cells (fluorescent spots) are located in the phloem 631 and outer bark for both species.

632 Figure 6. Percentage of bark living cells (\%BLC) stained with FDA in stem cross-sections in $P$. 633 lusitanica (panel A) and P. menziesii (panel B). "R" refers to recovering trees and "D" refers to dead 634 trees.

635 Table S1. Table summarizing the evolution of the PLC during the time-course of the experiment in A $636 P$. lusitanica and B P. menziesii. Control values represent the mean value of the measurements 637 performed before the drought event. BRW represents the measurements performed on the individuals 638 the day of the rehydration.

639 Table S2. Table summarizing the evolution of the stem relative water content $\left(\mathrm{RWC}_{\text {Stem }}\right)$, leaf relative 640 water content $\left(\mathrm{RWC}_{\text {Leaf }}\right)$ and electrolytes leakage (EL) during the time-course of the experiment in A $P$. 641 lusitanica and B P. menziesii. Control values represent the mean value of the measurements performed 642 before the drought event. BRW represents the measurements performed on the individuals the day of 643 the rehydration.

644 Table S3. Table summarizing the evolution of the percentage of bark living cells (\%BLC) during the 645 time-course of the experiment in A P. lusitanica and B P. menziesii. Control values represent the mean 646 value of the measurements performed before the drought event. BRW represents the measurements 647 performed on the individuals the day of the rehydration.

648 Figure S1. Validation of the stem water potential $\left(\Psi_{\text {stem }}\right)$ measurements recorded with psychrometer and 649 compared to the $\Psi_{\text {stem }}$ measurements carried out with the Scholander pressure chamber on previously 650 bagged leaves. A for P. lusitanica and B for P. menziesii.

651 Figure S2. Photographs of $P$. lusitanica plants flushing new leaves after experimenting a drought event 652 and reaching levels of PLC of 98.6\%. A 19 days after re-watering; B 28 days after re-watering. 


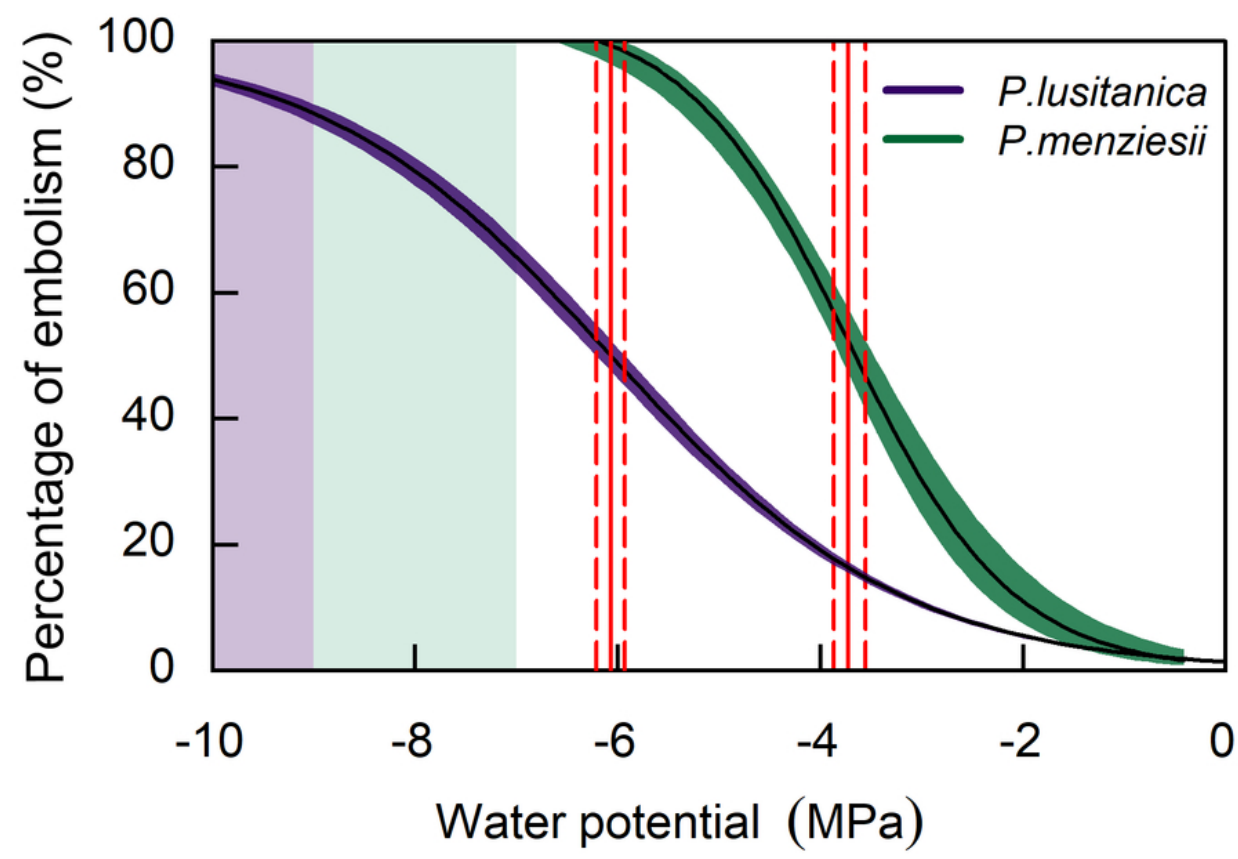

Figure 1. Vulnerability curves to cavitation for Prunus lusitanica L stems and Pseudotsuga menziesii M stems. Vulnerability curve for $P$. lusitanica stems obtained on four different samples using the optical method (Brodribb et al. 2017). The $P_{50}$ is evaluated at $-6.07 \mathrm{MPa}$ while the $P_{88}$ is evaluated at $-8.94 \mathrm{MPa}$. Vulnerability curve for $P$. menziesii stems obtained on five different samples using the Cavitron technique developed by Cochard in 2002 . The $P_{50}$ is evaluated at $-3.73 \mathrm{MPa}$ and $P_{88}$ is evaluated at $-5.34 \mathrm{MPa}$. Red solid lines represent the $P_{50}$ while red dashed lines represent the confidence interval around $P_{50}$ at $95 \%$. Violet and green rectangle correspond to the water potential values at which $P$. lusitanica and $P$. menziesii were respectively irrigated. 
Prunus lusitanica

Pseudotsuga menziesii

Box plots represents the dispersions of percentage loss of conductance (PLC) values for A Prunus lusitanica. $\mathrm{L}$ and $\mathbf{B}$ Pseudotsuga menziesii. M before water stress (control) and before re-watering for recovering (R) and dead (D) trees measured with the Xyl'em apparatus for $P$. Iusitanica and X-ray micro-CT for $P$. menziesii. 
Dynamic of the stem diameter (solid line) and evolution of the water potential (points) during the timecourse of the experiment. Stem diameter dynamic (in $\mu \mathrm{m}$ ) was recorded by LVDT for both species while the water potential was measured punctually using a Scholander pressure chamber for Prunus lusitanica individuals and continuously by psychrometers for Pseudotsuga menziesii individuals. The light grey rectangles represent the period where water was withhold to simulate a extreme drought event. Panels $\mathbf{A}$ and $\mathbf{B}$ show the recovery of individuals after re-watering in terms of stem diameter while panels $\mathbf{C}$ and $\mathbf{D}$ show dead individuals.

$132 \times 99 \mathrm{~mm}(300 \times 300 \mathrm{DPI})$ 


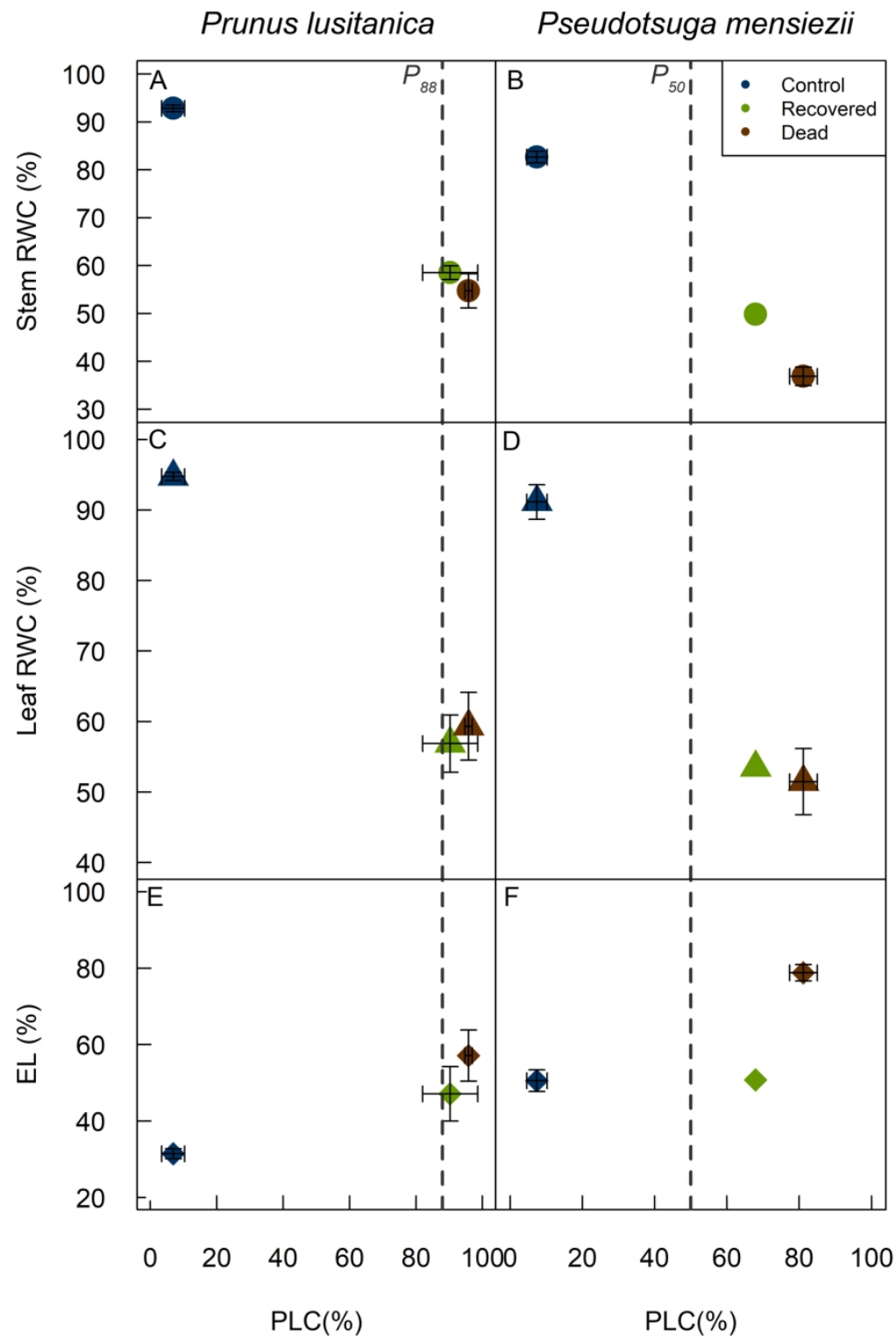

Variation of Stem Relative Water Content (RWCStem) (panels A and B), Leaf Relative Water Content

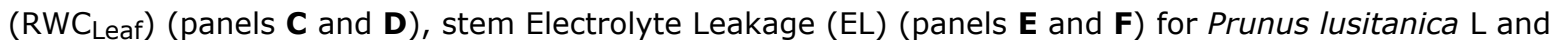
Pseudotsuga menziesii M. Measurements were performed on all individuals in control conditions (Control) and after the drought event (e.g. before the rehydration of the plants for recovered and dead individuals. 

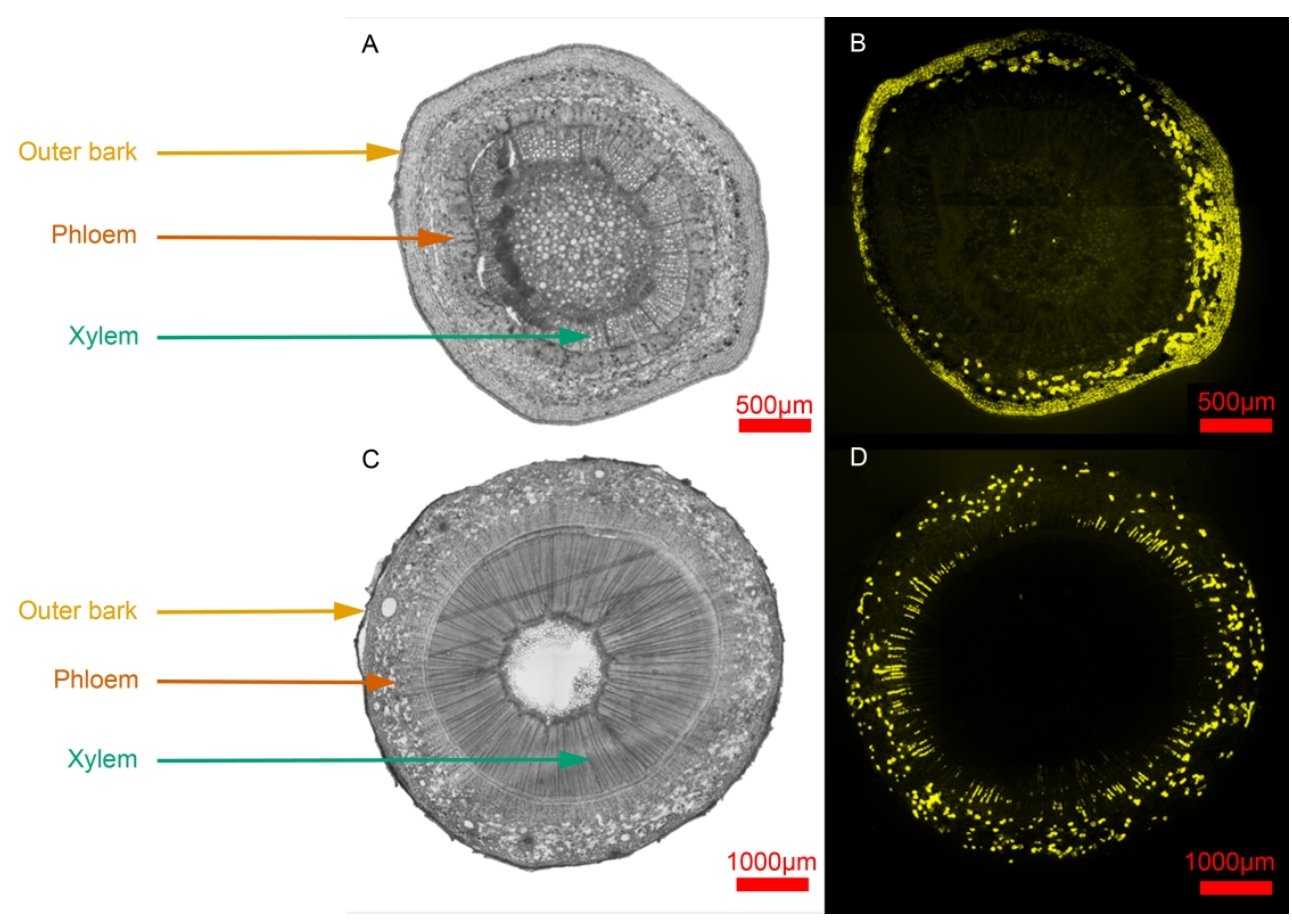

Cross sections of Prunus lusitanica L (A and B) and Pseudotsuga menziesii M (C and D) stems in control conditions. Cross sections were stained using fluorescein diacetate (FDA) (60 $\mu$ m thick cross section - $1 \%$ solution) and microphotographs were taken using a bright light ( $\mathbf{A}$ and $\mathbf{C}$ ) and an inverted fluorescence microscope (YFP filter B and D). Living cells (fluorescent spots) are located in the phloem and outer bark for both species. 


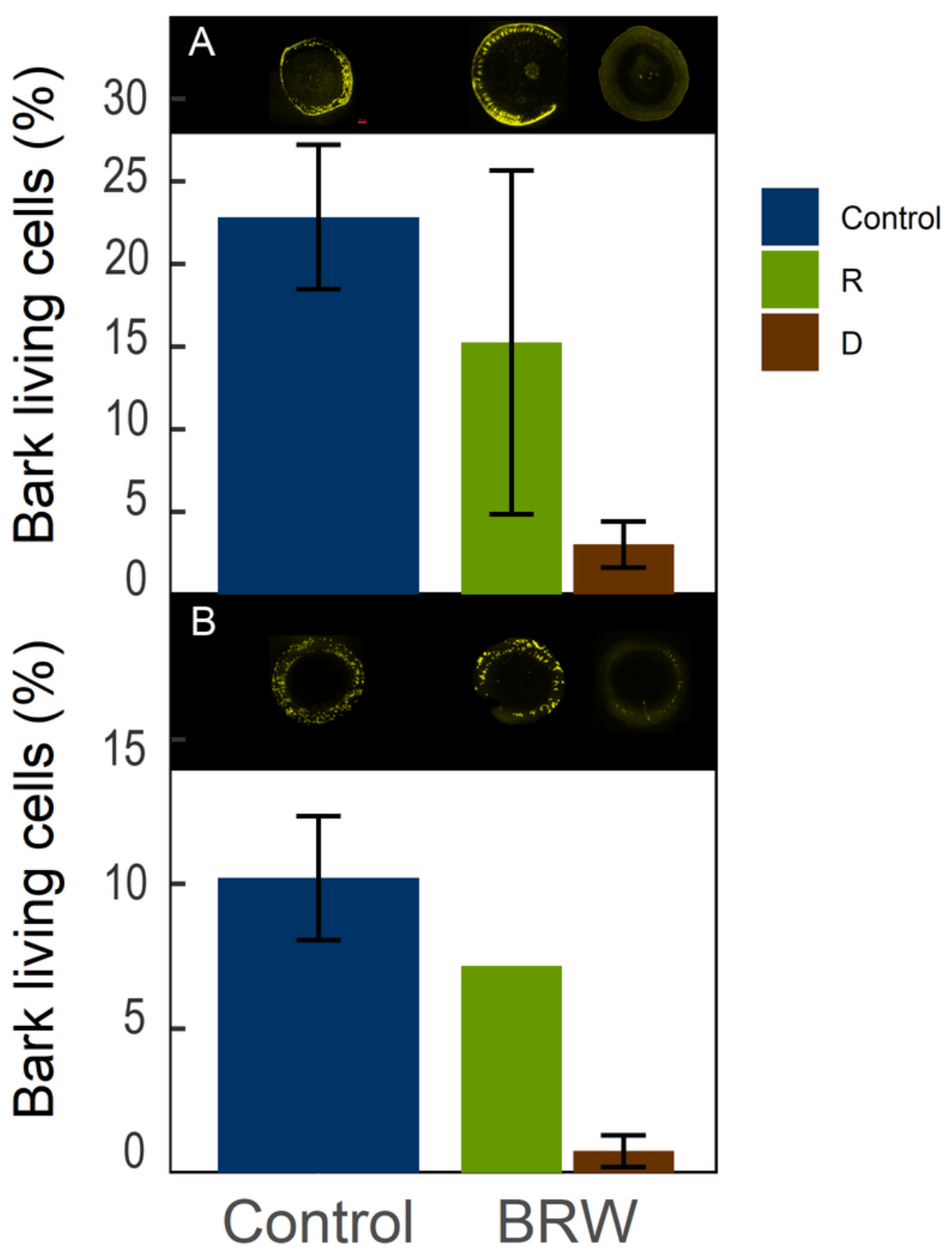

Percentage of bark living cells (\%BLC) stained with FDA in stem cross section in Prunus lusitanica $L$ (panel A) and Pseudotsuga menziesii M (panel B). "R" refers to recovering trees and "D" refers to dead trees. 